\title{
Monitoring the Pollution Level in Istanbul Coast of the Sea of Marmara Using Algal Species Ulva lactuca $\mathbf{L}$.
}

\author{
Ibrahim Ilker Ozyigit ${ }^{1 *}$, Omer Lutfi Uyanik², Necla Ruken Sahin³, \\ Ibrahim Ertugrul Yalcin², Goksel Demir ${ }^{4}$
}

${ }^{1}$ Marmara University, Faculty of Science and Arts, Department of Biology, 34722, Goztepe/Istanbul, Turkey

${ }^{2}$ Bahcesehir University, Faculty of Engineering and Natural Sciences, Department of Molecular Biology and Genetics, 34353, Besiktas/Istanbul, Turkey

${ }^{3}$ Bahcesehir University, Faculty of Engineering and Natural Sciences, Department of Environmental Engineering, 34353, Besiktas/Istanbul, Turkey

${ }^{4}$ Kirklareli University, Faculty of Architecture, Department of Urban and Regional Planning, 39020, Kayali/Kirklareli, Turkey

Received: 16 July 2016

Accepted: 20 October 2016

\begin{abstract}
Heavy metal pollution in coastal regions has become a serious problem due to significant environmental degradations. In the present study, an algal species, U. lactuca, was investigated to assess the impact of heavy metal pollution on the six different locations along the coastal line of the Sea of Marmara in Istanbul. Heavy metal and mineral nutrient elements such as $\mathrm{Ca}, \mathrm{Cd}, \mathrm{Cu}, \mathrm{Fe}, \mathrm{K}, \mathrm{Mg}, \mathrm{Mn}, \mathrm{Pb}$, and $\mathrm{Zn}$ were determined using ICP-OES. The following lowest and highest concentrations $(\mathrm{mg} / \mathrm{kg}$; dw) were measured in Ulva samples: $1,751.66-2,465.68$ for $\mathrm{Ca}, 0.45-3.22$ for $\mathrm{Cd}, 6.67-18.32$ for $\mathrm{Cu}$, 553.32-989.33 for $\mathrm{Fe}$, 3,264.48-4,301.68 for K, 961.50-1,614.53 for Mg, 8.27-25.32 for Mn, 4.93-19.32 for Pb, and 15.16-41.30 for $\mathrm{Zn}$. The data revealed that $U$. lactuca is capable of accumulating considerable amounts of metals. Besides, metal deposition in the plant did not alter the mineral nutrient uptake pattern extensively, indicating relatively less contamination risk in the area. Overall, the comparison of heavy metal contents with seawater and sediment samples in the Ulva species showed that $U$. lactuca is a suitable plant for biomonitoring studies.
\end{abstract}

Keywords: sea lettuce, chlorophyta, heavy metal pollution, mineral nutrient uptake 


\section{Introduction}

Anthropogenic and industrial-based activities release high amounts of heavy metals into aquatic environments, which significantly disturbs marine life due to their toxic and accumulative natures [1-3]. Recently, heavy metal-related pollution in coastal regions has become a serious problem because of its significant environmental degradation [4]. Thus, environmentally friendly and efficient alternative technologies are required to clean the heavy metal-polluted waters [5].

Despite its imprecise definition, metals of higher than $5 \mathrm{~g} / \mathrm{cm}^{3}$ densities are regarded as heavy metals [6]. Some heavy metals in nature, such as $\mathrm{Cd}, \mathrm{Hg}$, and $\mathrm{Pb}$, are not required by living organisms, therefore their presence, even in minor amounts, is toxic [7]. However, certain doses (trace amounts) of some heavy metals such as $\mathrm{Cu}$ and $\mathrm{Cr}$ (for plants), and $\mathrm{Fe}, \mathrm{Mn}, \mathrm{Mo}, \mathrm{Zn}$, and $\mathrm{Ni}$ are required by plants for healthy life cycles [8-10]. The over-accumulation or toxicity of heavy metals could cause serious consequences for biological systems by disturbing cell functions, finally leading to the formation of various symptoms or death of an organism [11]. Biologically, heavy metals could induce the production of ROS species, which interferes with functions of DNA, proteins, and lipids, and causes the oxidative stress leading to cell death [12-14].

Some organisms are considered as biomonitors or bioindicators to evaluate certain characteristics of the biosphere [15-16]. Using biological species in biomonitoring aquatic systems could allow for evaluation of the presence of contaminants and/or their effects on nearby living ecosystems. In addition, analysis of aquatic components such as water or sediment by relevant biomonitors could provide an overall perception about the contaminants rather than only a small fraction of eco-toxicological indications. Therefore, it considerably reduces or eliminates the requirement of complex investigations on chemical speciation of contaminants [4].

Green algae species show a widespread distribution in various freshwater ecosystems with significantly different physical and chemical parameters. They are very relevant organisms for aquatic biomonitoring studies because of their heavy metal uptake capacity, affinity of multiple elements, sedentary lifestyle, considerable biomass, and easy characterization [17-18]. Algae could bind the aquatic free metal ions via carbohydrate, protein, or lipid molecules in the cell wall surface; the density of these molecules varies depending on the nature and concentrations of the metal ions [2, 19-20]. Metal ion concentration and biomass, temperature, $\mathrm{pH}$, cations/ anions, and metabolic stage of algae significantly affect metal adsorption [21-23].

Ulva lactuca L., which is a member of Ulvaceae family, is a well-known and approved biomonitoring plant, and many studies are available indicating the use of this species for monitoring aquatic pollutants in various marine systems [13, 17-18, 24-29]. This species has widespread distribution along the shores of Turkey and grows well along the coastal lines of the Sea of Marmara. It could accumulate high nutrient levels from contaminated or polluted environments [25]. Therefore, the present study aimed to obtain further information about the use of $U$. lactuca as a biomonitoring algae species along the Istanbul coast of the Sea of Marmara, Turkey, and to provide information about marine environmental quality as well as degree of pollution.

\section{Materials and Methods}

\section{Study Area}

According to the 2014 consensus, Istanbul is one of the largest cities of Turkey with about 15 million inhabitants [30]. It is also the cultural, economic, and financial center of Turkey. It is located in northwestern Turkey in the Marmara region within an area of 5,343 $\mathrm{km}^{2}$ [31-32]. In addition, it employs around $27 \%$ of Turkey's industrial workforce and provides $40 \%$ of Turkey's industrial workspace [33]. The Sea of Marmara, which is entirely located within Turkey's border as an inland sea, connects the Black and Aegean Seas and separates the Asian and European parts of Turkey. It covers an area of $11,350 \mathrm{~km}^{2}$ $(280 \times 80 \mathrm{~km})$ and is $1,370 \mathrm{~m}$ at its deepest point [34-35].

The Sea of Marmara has faced heavy pollution since the 1980s. The main sources of pollution are especially heavy industrial facilities in the Gulf of Izmit near Istanbul and waste from such densely populated cities as Istanbul and Izmit to the northeast. Today, 0.3 million $\mathrm{m}^{3}$ industrial and 2.1 million $\mathrm{m}^{3}$ of domestic waste is produced daily [33].

In the present study, U. lactuca samples were collected from six different locations along the coastal line of the Sea of Marmara in Istanbul. These locations include the Buyukada, Fenerbahce, Maltepe, Bakirkoy, Beykoz, and Beylikduzu coasts (Fig. 1).

\section{Plant Sample Analysis}

Plant samples (eight individuals) were collected from six different locations approximately 50-100 cm depth during the third and fourth weeks of February 2014. Samples were washed with distilled water to eliminate the dust particles as specified in standardized procedure and then oven-dried at $80^{\circ} \mathrm{C}$ for 24 h. $0.2 \mathrm{~g}$ of each sample was transferred in Teflon vessels and then $8 \mathrm{~mL}$ of 65 $\mathrm{wt} \% \mathrm{HNO}_{3}$ solution (Merck) was added to each sample. Samples were dissolved in a Berghof-MWS2 microwave oven set on $5 \mathrm{~min}$ at $145^{\circ} \mathrm{C}, 5 \mathrm{~min}$ at $165^{\circ} \mathrm{C}$, and $20 \mathrm{~min}$ at $175^{\circ} \mathrm{C}$. Later, samples were filtered with filter papers of 1-2 $\mu \mathrm{m}$ average pore diameter, and then transferred to volumetric falcon tubes to which up to $50 \mathrm{~mL}$ ultrapure water was added. For each sample, $\mathrm{Ca}, \mathrm{Cd}, \mathrm{Cu}, \mathrm{Fe}, \mathrm{K}$, $\mathrm{Mg}, \mathrm{Mn}, \mathrm{Pb}$, and $\mathrm{Zn}$ concentrations were measured using inductively coupled plasma optical emission spectroscopy (ICP-OES, Perkin Elmer-Optima 7000 DV). 


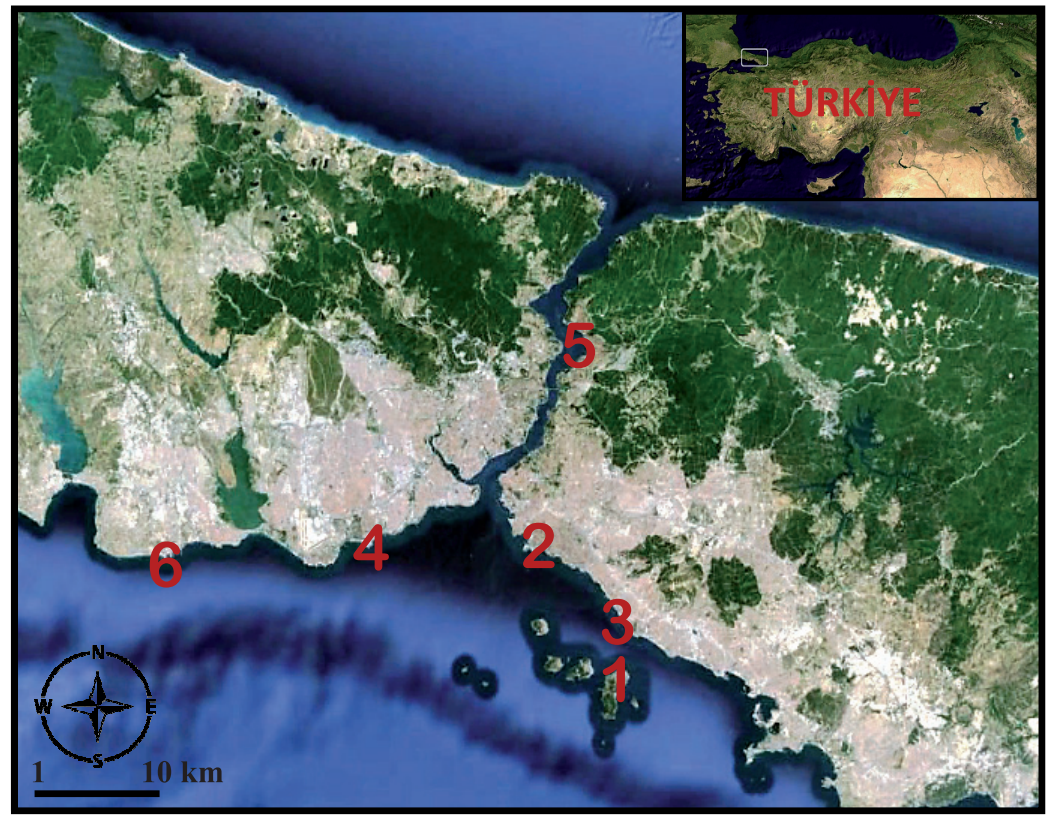

Fig. 1. Study areas in Istanbul Province, Turkey: 1) Buyukada Coast, 2) Fenerbahce Coast, 3) Maltepe Coast, 4) Bakirkoy Coast, 5) Beykoz Coast, and 6) Beylikduzu Coast.

\section{Statistical Analysis}

For statistical analysis, one-way analyses of variance (ANOVA) with Tukey's post-hoc HSD were performed using IBM SPSS Statistics 20 software. The statistical significance levels were indicated as ${ }^{* *} \mathrm{P}<0.01$ and ${ }^{*} \mathrm{P}<0.05$.

\section{Results and Discussion}

The mineral nutrient and heavy metal contents of $U$. lactuca samples are given in Table 1. The average of highest and lowest concentrations of each element are:

- Ca: the average highest concentration $(2,465.684 \mathrm{mg} /$

$\mathrm{kg}$ ) was measured in Buyukada samples while the average lowest concentration $(1,751.661 \mathrm{mg} / \mathrm{kg})$ was in Beylikduzu

- Cd: the average highest concentration $(3.218 \mathrm{mg} / \mathrm{kg})$ was found in Beylikduzu samples while the average lowest concentration $(0.451 \mathrm{mg} / \mathrm{kg})$ was in Buyukada

- $\mathrm{Cu}$ : the average highest concentration $(18.315 \mathrm{mg} /$ $\mathrm{kg}$ ) was obtained in Beylikduzu samples while the average lowest concentration $(6.671 \mathrm{mg} / \mathrm{kg})$ was in Buyukada

- Fe: the average highest concentration $(989.328 \mathrm{mg} /$ $\mathrm{kg}$ ) was observed in Beylikduzu samples while the average lowest concentration $(553.318 \mathrm{mg} / \mathrm{kg})$ was in Buyukada

- $\mathrm{K}$ : the average highest concentration $(4,301.681 \mathrm{mg} /$ $\mathrm{kg}$ ) was measured in Beylikduzu samples while the

Table 1. Mineral element and heavy metal concentrations $(\mathrm{mg} / \mathrm{kg} \mathrm{dw}$.) of $U$. lactuca. Statistical analyses such as one-way analysis of variance (ANOVA) with Tukey's post-hoc HSD were performed. The mean differences are significant at $p<0.01\left(^{* *}\right)$ and $p<0.05\left(^{*}\right)$ levels. The letters a, b, c, and d indicate different averages within the same line, which are significant in terms of averages $(\mathrm{p}<0.05)$.

\begin{tabular}{|c|c|c|c|c|c|c|}
\hline & Buyukada & Fenerbahce & Maltepe & Bakirkoy & Beykoz & Beylikduzu \\
\hline $\mathrm{Ca}$ & $2,465.684 \pm 33.231^{\mathrm{a}}$ & $2,159.529 \pm 28.556^{* a b}$ & $2,066.894 \pm 23.504^{* b}$ & $1,864.715 \pm 17.226^{* * \mathrm{bc}}$ & $1,808.659 \pm 16.164^{* * \mathrm{c}}$ & $1,751.661 \pm 15.319^{* *_{c}}$ \\
\hline $\mathrm{Cd}$ & $0.451 \pm 0.012^{\mathrm{d}}$ & & $1.489 \pm 0.029^{* \mathrm{c}}$ & & $2.596 \pm 0.041^{* \mathrm{~b}}$ & $3.218 \pm 0.053^{* a}$ \\
\hline $\mathrm{Cu}$ & $6.671 \pm 0.101^{\mathrm{d}}$ & & $13.007 \pm 0.155^{* b}$ & $15.282 \pm 0.167^{* * b}$ & $16.339 \pm 0.185^{* b}$ & $18.315 \pm 0.201^{* * a}$ \\
\hline $\mathrm{Fe}$ & $553.318 \pm 10.981^{\mathrm{c}}$ & $686.148 \pm 13.057^{* \mathrm{~b}}$ & $721.229 \pm 16.122^{* b}$ & $775.318 \pm 19.154^{* b}$ & $882.157 \pm 23.185^{* a}$ & $989.328 \pm 29.210^{* a}$ \\
\hline K & $3,264.478 \pm 39.315^{\mathrm{c}}$ & $3,555.217 \pm 41.526^{* b}$ & $3,601.253 \pm 40.669^{* b}$ & $3,821.644 \pm 43.457^{* \mathrm{~b}}$ & $3,900.335 \pm 45.854^{* b}$ & $4,301.681 \pm 41.746^{* a}$ \\
\hline $\mathrm{Mg}$ & $1,614.533 \pm 14.521^{\mathrm{a}}$ & $1,401.121 \pm 13.78^{8 * * a b}$ & $1,361.524 \pm 15.959^{* b}$ & $1,111.625 \pm 10.013^{* b}$ & $1,035.006 \pm 13.338^{*^{\mathrm{c}}}$ & $961.497 \pm 8.615^{* *_{\mathrm{c}}}$ \\
\hline $\mathrm{Mn}$ & $8.267 \pm 0.092^{\mathrm{d}}$ & $13.329 \pm 0.172^{*_{\mathrm{c}}}$ & $15.208 \pm 0.201^{* \mathrm{c}}$ & $18.224 \pm 0.245^{* b}$ & $20.339 \pm 0.287^{* b}$ & $25.318 \pm 0.314^{* a}$ \\
\hline $\mathrm{Pb}$ & $4.927 \pm 0.070^{\mathrm{d}}$ & $7.628 \pm 0.095^{* \mathrm{c}}$ & $8.918 \pm 0.104^{* *_{\mathrm{c}}}$ & $12.355 \pm 0.196^{* b}$ & $16.297 \pm 0.221^{* a}$ & $19.315 \pm 0.246^{* a}$ \\
\hline $\mathrm{Zn}$ & $15.157 \pm 0.222^{\mathrm{c}}$ & $22.229 \pm 0.519^{* b}$ & $26.871 \pm 0.735^{* b}$ & $31.882 \pm .811^{* \mathrm{~b}}$ & $35.328 \pm 0.924^{* a}$ & $41.297 \pm 1.015^{* a}$ \\
\hline
\end{tabular}


average lowest concentration $(3,264.478 \mathrm{mg} / \mathrm{kg})$ was in Buyukada

- Mg: the average highest concentration (1614.533 $\mathrm{mg} / \mathrm{kg}$ ) was determined in Buyukada samples while average lowest concentration $(961.497 \mathrm{mg} / \mathrm{kg})$ was in Beylikduzu

- Mn: the average highest concentration $(25.318 \mathrm{mg} /$ $\mathrm{kg}$ ) was found in Beylikduzu samples while average lowest concentration $(8.267 \mathrm{mg} / \mathrm{kg})$ was in Buyukada

- $\quad \mathrm{Pb}$ : the average highest concentration $(19.315 \mathrm{mg} / \mathrm{kg}$ ) was obtained in Beylikduzu samples while average lowest concentration $(4.927 \mathrm{mg} / \mathrm{kg})$ was in Buyukada

- $\mathrm{Zn}$ : the average highest concentration $(41.297 \mathrm{mg} /$ $\mathrm{kg}$ ) was observed in Beylikduzu samples while average lowest concentration $(15.157 \mathrm{mg} / \mathrm{kg})$ was in Buyukada.

In most of the locations, such as the Buyukada, Fenerbahce, Maltepe, Bakirkoy, and Beykoz coasts, mineral nutrient and heavy metal contents in $U$. lactuca samples decreased in the following order: $\mathrm{K}>\mathrm{Ca}>\mathrm{Mg}>\mathrm{Fe}>\mathrm{Zn}>\mathrm{Mn}>\mathrm{Cu}>\mathrm{Pb}>\mathrm{Cd}$. However, in Beylikduzu it was $\mathrm{K}>\mathrm{Ca}>\mathrm{Mg}>\mathrm{Fe}>\mathrm{Zn}>\mathrm{Mn}>\mathrm{Pb}>\mathrm{Cu}>\mathrm{Cd}$ (Table 1).

Many studies have reported some members of the Ulva genus for their biomonitoring potential [13, 17, 2628]. For example, $U$. lactuca was reported as a biomonitor plant for $\mathrm{Cd}, \mathrm{Fe}, \mathrm{Mn}$, and $\mathrm{Pb}$ elements, while $U$. rigida was for $\mathrm{Cd}, \mathrm{Pb}$, and $\mathrm{Zn}$ [36-37]. U. clathrata, U. linza, and $U$. flexuosa species were reported for $\mathrm{Cd}, \mathrm{Cu}, \mathrm{Pb}$, and $\mathrm{Zn}$ metals [38]. In a recent study, U. lactuca was demonstrated as an effective bio-sorbent for the removal of $\mathrm{Cu}, \mathrm{Cd}, \mathrm{Pb}$, and $\mathrm{Zn}$ from synthetic solutions [39]. Many other studies have also reported similar results; therefore, to avoid repetitive arguments with close interpretations, a comparison table was formed to show the heavy metal contents in $U$. lactuca from various locations, and the results obtained from the present study (Table 2). Based on comparisons of present study results with the available literature of $U$. lactuca demonstrating that $\mathrm{Cd}, \mathrm{Cu}, \mathrm{Fe}$, and $\mathrm{Zn}$ in Vadinar, India [13]; Cd and Pb in the Red Sea, Egypt [24]; $\mathrm{Cu}$ and $\mathrm{Mn}$ in Malta Lake, Poland [28]; Fe and Mn in Mikindani, Kenya [27]; and Mn in Chincoteague Island, Virginia and Msimbazi, Tanzania [17, 27]; Mn and Zn in Nielba River, Poland [28]; and Zn in Canakkale and Izmir, Turkey and Sikka, India $[4,13]$ were relatively higher than the findings of the present study.

A greater amount of heavy metal pollution in Beylikduzu Coast samples could be explained by the influence of the connection between Kucukcekmece Lagoon and the sea. Particularly, in recent years, the pollution rate of Kucukcekmece Lagoon has significantly increased due to anthropogenic factors. Overurbanization in the vicinity of the lagoon and unprocessed industrial wastes caused an increase in heavy metal entries to the lagoon and consequently to the sea through the connection [44]. Excessive heavy metal content at Beykoz Coast may

Table 2. Heavy metal concentrations ( $\mathrm{mg} / \mathrm{kg} \mathrm{dw}$.) of U. lactuca in different regions in the last decade.

\begin{tabular}{|c|c|c|c|c|c|c|c|c|}
\hline Species & Study Area & $\mathrm{Cd}$ & $\mathrm{Cu}$ & $\mathrm{Fe}$ & $\mathrm{Mn}$ & $\mathrm{Pb}$ & $\mathrm{Zn}$ & Reference \\
\hline Ulva lactuca & Egyptian Red Sea & 5.30 & 8.30 & - & 16.90 & 37.20 & 40.70 & {$[24]$} \\
\hline Ulva lactuca & $\begin{array}{l}\text { Chincoteague } \\
\text { Island, Virginia }\end{array}$ & - & 0.69 & - & 50.45 & - & 12.95 & {$[17]$} \\
\hline Ulva lactuca & $\begin{array}{c}\text { Assateague } \\
\text { Island, Maryland }\end{array}$ & - & 0.65 & - & 22.40 & - & 6.86 & {$[17]$} \\
\hline Ulva lactuca & Black Sea, Turkey & 0.023 & 3.93 & 784.0 & 19.10 & 0.648 & 22.40 & {$[25]$} \\
\hline Ulva lactuca & Canakkale, Turkey & 0.054 & 8.51 & 197.6 & - & 0.0056 & 50.10 & {$[4]$} \\
\hline Ulva lactuca & Izmir, Turkey & 0.014 & 13.90 & 129.6 & - & 0.0175 & 67.80 & {$[4]$} \\
\hline Ulva lactuca & Jijel, Algeria & 0.041 & 2.37 & - & - & 1.001 & 5.40 & {$[26]$} \\
\hline Ulva lactuca & Chale, Kenya & 0.955 & 5.15 & 350.0 & 20.55 & - & 18.50 & {$[27]$} \\
\hline Ulva lactuca & Mikindani, Kenya & 0.150 & 13.60 & 4000 & 325.0 & - & 32.50 & {$[27]$} \\
\hline Ulva lactuca & Msimbazi, Tanzania & 0.110 & 15.80 & 900.0 & 40.80 & - & 17.30 & {$[27]$} \\
\hline Ulva lactuca & Itaparica Island, Penha Beach, Brazil & 0.265 & 3.13 & - & 10.60 & 0.729 & 10.20 & {$[18]$} \\
\hline Ulva lactuca & Nielba River, Poland & - & 11.37 & - & 323.85 & - & 157.9 & {$[28]$} \\
\hline Ulva lactuca & Malta Lake, Poland & - & 18.47 & - & 549.90 & - & 36.34 & {$[28]$} \\
\hline Ulva lactuca & Sikka, India & 2.89 & 14.20 & 948.0 & 7.70 & 3.50 & 146.0 & [13] \\
\hline Ulva lactuca & Vadinar, India & 3.60 & 21.50 & 1256 & 7.60 & 0.80 & 340.0 & [13] \\
\hline Ulva lactuca & Vadinar, India & 2.76 & 16.00 & 1439 & 7.80 & 1.00 & 326.0 & [13] \\
\hline Ulva lactuca & Magallanes, Chile & - & 6.97 & 720.0 & 27.20 & - & 16.20 & [29] \\
\hline
\end{tabular}


be attributed to uncontrolled wastewater. The municipality has made efforts to solve this problem by constructing the Kavacık-Pasabahce-Beykoz sewer system. For the same reason, the Atakoy Advanced Wastewater Treatment Plant was constructed along the Bakirkoy Coast in 2010. In this way, wastewater discharge to Bakirkoy has been prevented and hence pollution along this coast has significantly decreased. The reason for low heavy metal contents at Fenerbahce and Maltepe coasts is a better level of infrastructure systems in these locations, thus avoiding wastewater discharge [33].

The average highest $\mathrm{Ca}$ and $\mathrm{Mg}$ concentrations were in Buyukada samples, while the average lowest concentrations were in Beylikduzu (Table 1). This observation is just the opposite of that obtained for heavy metals $(\mathrm{Cd}, \mathrm{Cu}, \mathrm{Fe}, \mathrm{Mn}, \mathrm{Pb}$, and $\mathrm{Zn})$. Therefore, in $U$. lactuca samples, uptake of $\mathrm{Ca}$ and $\mathrm{Mg}$ has a negative effect on uptake of other heavy metals $[7,10]$. In addition, $\mathrm{Cd}$ and $\mathrm{Pb}$ concentrations, which are potential toxic elements [40], were investigated to have an insight about the pollution levels on various coasts of Istanbul. The highest concentrations of these heavy metals were mainly observed at Beylikduzu Coast, indicating the pollution level of this coastal region. In a study, sediment samples collected from the Bosphorus were reported to contain high levels of $\mathrm{Cd}$ and $\mathrm{Pb}$ compared to other investigated regions [41]. In the present study, after the Beylikduzu Coast, the second highest heavy metal contents were measured in the Bosphorus. In addition, many similar studies have reported a high level of heavy metals in sediment and water samples collected from Bakirkoy, Beylikduzu, and Bosphorus locations [35, 42-43].

Overall, the comparison of heavy metal contents with seawater and sediment samples [35, 40, 41-43] in Ulva species showed that $U$. lactuca is a good candidate for biomonitoring studies.

\section{Conclusions}

The release of heavy metals in coastal regions has been a serious threat to aquatic environments. Although certain heavy metals in trace amounts could be tolerated by plants, they are usually toxic. So their presence and concentrations in water must be regularly monitored in terms of sustainability of aquatic environments. However, this should be done in a more environmentally friendly and efficient way. To achieve this, employing biological species as biomonitors to evaluate the presence of contaminants and/or their effects on the environment has been regarded as an alternative. In this sense, the present work used the $U$. lactuca algal species as a biomonitoring plant to provide insights about the water quality and pollution levels along the Istanbul Coast of the sea of Marmara. The analysis of plant samples using ICP-OES revealed that $U$. lactuca is capable of accumulating metals to some extent, although this deposition did not significantly change the overall mineral nutrient status of plants. This shows that $U$. lactuca could be used as a potential biomonitoring plant. Furthermore, from a biotechnological perspective the engineering of this algal species could produce new plant lines with enhanced metal accumulation capacities.

\section{Acknowledgements}

The authors wish to thank Bahcesehir University for their technical support. We also wish to thank Dr. Recep Vatansever for rechecking the language in this document.

\section{References}

1. FREITAS O.M., MARTINS R.J., DELERUE-MATOS C.M., BOAVENTURA R.A. Removal of Cd (II), Zn (II) and $\mathrm{Pb}$ (II) from aqueous solutions by brown marine macro algae: kinetic modelling. J Hazard Mater. 153 (1), 493, 2008.

2. BULGARIU D., BULGARIU L. Equilibrium and kinetics studies of heavy metal ions biosorption on green algae waste biomass. Bioresource Technol. 103 (1), 489, 2012.

3. OSMA E., ILHAN V., YALCIN I.E. Heavy metals accumulation causes toxicological effects in aquatic Typha domingensis Pers. Braz J Bot. 37 (4), 461, 2014.

4. AKCALI I., KUCUKSEZGIN F. A biomonitoring study: heavy metals in macroalgae from eastern Aegean coastal areas. Mar Pollut Bull. 62 (3), 637, 2011.

5. IBRAHIM W.M. Biosorption of heavy metal ions from aqueous solution by red macroalgae. J Hazard Mater. 192 (3), 1827, 2011.

6. DUFFUS J.H. "Heavy metals" a meaningless term? (IUPAC Technical Report). Pure Appl Chem. 74 (5), 793, 2002.

7. YASAR U., OZYIGIT I.I., YALCIN I.E., DOGAN I., DEMIR G. Determination of some heavy metals and mineral nutrients of bay tree (Laurus nobilis L.) in Bartin city, Turkey. Pak J Bot. 44, 81, 2012.

8. OSMA E., OZYIGIT I.I., LEBLEBICI Z., DEMIR G., SERIN M. Determination of heavy metal concentrations in tomato (Lycopersicon esculentum Miller) grown in different station types. Rom Biotech Lett. 17 (1), 6963, 2012.

9. VAN DER ENT A., BAKER A.J., REEVES R.D., POLLARD A.J., SCHAT H. Hyperaccumulators of metal and metalloid trace elements: facts and fiction. Plant Soil. 362 (1-2), 319, 2013.

10. SEVEROGLU Z., OZYIGIT I.I., DOGAN I., KURMANBEKOVA G., DEMIR G., YALCIN I.E., KASOGLU KARI G. The usability of Juniperus virginiana L. as a biomonitor of heavy metal pollution in Bishkek City, Kyrgyzstan, Biotechnol Biotec Eq. 28 (6), 1104, 2015.

11. HALL J.L. Cellular mechanisms for heavy metal detoxification and tolerance. J Exp Bot. 53 (366), 1, 2002.

12. KANNAN K., JAIN S.K. Oxidative stress and apoptosis. Pathophysiol. 7 (3), 153, 2000.

13. CHAKRABORTY S., BHATTACHARYA T., SINGH G., MAITY J.P. Benthic macroalgae as biological indicators of heavy metal pollution in the marine environments: A biomonitoring approach for pollution assessment. Ecotox Environ Safe. 100, 61, 2014.

14. PEREIRA P., DE PABLO H., GUILHERME S., CARVALHO S., SANTOS M.A., VALE C., PACHECO $M$. Metal accumulation and oxidative stress responses in Ulva spp. in the presence of nocturnal pulses of metals from sediment: A field transplantation experiment under eutrophic conditions. Mar Environ Res. 94, 56, 2014. 
15. MARKERT B. Plants as biomonitors: indicators for heavy metals in the terrestrial environment. VCH Publishers Ltd. 1993.

16. WOLTERBEEK B. Biomonitoring of trace element air pollution: principles, possibilities and perspectives. Environ Pollut. 120 (1), 11, 2002.

17. CHAUDHURI A., MITRA M., HAVRILLA C., WAGUESPACK Y., SCHWARZ J. Heavy metal biomonitoring by seaweeds on the Delmarva Peninsula, east coast of the USA. Bot Mar, $\mathbf{5 0}$ (3), 151, 2007.

18. BRITO G.B., DE SOUZA T.L., BRESSY F.C., MOURA C.W., KORN M.G.A. Levels and spatial distribution of trace elements in macroalgae species from the Todos os Santos Bay, Bahia, Brazil. Mar Pollut Bull. 64 (10), 2238, 2012.

19. SALGADO L.T., ANDRADE L.R., AMADO FILHO G.M. Localization of specific monosaccharides in cells of the brown alga Padina gymnospora and the relation to heavymetal accumulation. Protoplasma. 225 (1-2), 123, 2005.

20. JI L., XIE S., FENG J., LI Y., CHEN L. Heavy metal uptake capacities by the common freshwater green alga Cladophora fracta. J Appl Phycol. 24 (4), 979, 2012.

21. MEHTA S.K., GAUR J.P. Use of algae for removing heavy metal ions from wastewater: progress and prospects. Crit Rev Biotechnol. 25 (3), 113, 2005.

22. MESSYASZ B. Enteromorpha (Chlorophyta) populations in the Nielba river and lake Laskownickie. 2006.

23. ELREFAII A.H., SALLAM L.A., HAMDY A.A., AHMED E.F. Optimization of some heavy metals biosorption by representative egyptian marine algae1. J Phycol. 48 (2), 471, 2012.

24. ABDALLAH A.M.A., ABDALLAH M.A., BELTAGY A.I. Contents of heavy metals in marine seaweeds from the Egyptian coast of the Red Sea. Chem Ecol, 21 (5), 399, 2005.

25. TUZEN M., VEREP B., OGRETMEN A.O., SOYLAK M. Trace element content in marine algae species from the Black Sea, Turkey. Environ Monit Assess. 151 (1-4), 363, 2009.

26. LAIB E., LEGHOUCHI E. $\mathrm{Cd}, \mathrm{Cr}, \mathrm{Cu}, \mathrm{Pb}$, and $\mathrm{Zn}$ concentrations in Ulva lactuca, Codium fragile, Jania rubens, and Dictyota dichotoma from Rabta Bay, Jijel (Algeria). Environ Monit Assess. 184 (3), 1711, 2012.

27. OKUKU E.O., PETER H.K. Choose of heavy metals pollution biomonitors: a critic of the method that uses sediments total metals concentration as the benchmark. Int J Environ Res. 6 (1), 313, 2011.

28. RYBAK A., MESSYASZ B., PIKOSZ M., SZENDZINA L., ŁESKA B. Accumulation of heavy metals $(\mathrm{Co}, \mathrm{Cr}, \mathrm{Cu}$, $\mathrm{Mn}, \mathrm{Zn})$ in the freshwater alga Ulva type, sediments and water of the Wielkopolska region, Poland. Nauka Przyroda Technologie. 7 (4) 66, 1, 2013.

29. ASTORGA-ESPAÑA M.S., GALDÓN B.R., RODRÍGUEZ E.R., ROMERO C.D. Mineral and trace element concentrations in seaweeds from the sub-Antarctic ecoregion of Magallanes (Chile). J Food Compos Anal. 39, 69, 2015.

30. TUIK, 2015. The Official Web Site of Turkish Republic Office of Prime Ministry Statistics Institution. http://www. tuik.gov.tr/
31. ALTAY V., OZYIGIT I.I., YARCI C. Urban flora and ecological characteristics of the Kartal District (Istanbul): A contribution to urban ecology in Turkey. Sci Res Essays. 5 (2), 183, 2010.

32. OZDEMIR H., MERTOGLU B., DEMIR G., DENIZ A., TOROS H. Case study of PM pollution in playgrounds in Istanbul. Theor Appl Climatol. 108 (3-4), 553, 2012.

33. IBB, 2015. The Official Web Site of Istanbul Metropolis Municipality. http://www.ibb.gov.tr/

34. ALOISI G., SOULET G., HENRY P., WALLMANN K., SAUVESTRE R., VALLET-COULOMB C., BARD E. Freshening of the Marmara Sea prior to its post-glacial reconnection to the Mediterranean Sea. Earth Planet Sc Lett. 413, 176, 2015.

35. UNLU S., ALPAR B. An assessment of metal contamination in the shelf sediments at the southern exit of Bosphorus Strait, Turkey. Toxicol Environ Chem. 97 (6), 723, 2015.

36. HARITONIDIS S., MALEA P. Bioaccumulation of metals by the green alga Ulva rigida from Thermaikos Gulf, Greece. Environ Pollut. 104 (3), 365, 1999.

37. BOUBONARI T., MALEA P., KEVREKIDIS T. The green seaweed Ulva rigida as a bioindicator of metals $(\mathrm{Zn}, \mathrm{Cu}, \mathrm{Pb}$ and $\mathrm{Cd}$ ) in a low-salinity coastal environment. Bot Mar. $\mathbf{5 1}$ (6), 472, 2008.

38. SEELIGER U., WALLNER M. Multispecies metal monitoring in tropical Brazilian estuaries. In Metals in coastal environments of Latin America (pp. 258-269). Springer Berlin Heidelberg. 1988.

39. ARECO M.M., HANELA S., DURAN J., DOS SANTOS AFONSO M. Biosorption of $\mathrm{Cu}$ (II), Zn (II), Cd (II) and $\mathrm{Pb}$ (II) by dead biomasses of green alga Ulva lactuca and the development of a sustainable matrix for adsorption implementation. J Hazard Mater. 213, 123, 2012.

40. SEBASTIANI L., SCEBBA F., TOGNETTI R. Heavy metal accumulation and growth responses in poplar clones Eridano (Populus deltoides $\times$ maximowiczii) and I-214 (P. $\times$ euramericana) exposed to industrial waste. Environ Exp Bot. 52 (1), 79, 2004

41. ALGAN O., BALKIS N., CAGATAY M.N., SARI E. The sources of metal contents in the shelf sediments from the Marmara Sea, Turkey. Environ Geol. 46 (6-7), 932, 2004.

42. YIGITERHAN O., MURRAY J.W., TUGRUL S. Trace metal composition of suspended particulate matter in the water column of the Black Sea. Mar Chem. 126 (1), 207, 2011.

43. BOZKURT E., ELIRI O., KESIKTAS M. Analysis of heavy metals in seawater samples collected from beaches of Asian side of Istanbul. Journal of Recreation and Tourism Research. 1 (1), 39, 2014.

44. YILMAZ N. Diversity of phytoplankton in Kucukcekmece Lagoon channel, Turkey. Maejo International Journal of Science and Technology, 9 (1), 32, 2015. 